\title{
Bibliometric analysis of research on soil arsenic during 2005-2016
}

\author{
CUI Meng-qian(崔梦倩), WU Chuan(吴川), JIANG Xing-xing(江星星), \\ LIU Zi-yu(刘梓毓), XUE Sheng-guo(薛生国)
}

School of Metallurgy and Environment, Central South University, Changsha 410083, China

(C) Central South University Press and Springer-Verlag GmbH Germany, part of Springer Nature 2019

\begin{abstract}
Bibliometrics is an important branch in the field of information science, and it is widely used in many disciplines in modern research. A current active research subject can be analyzed and summarized from many aspects, such as the core institutions, core authors, highly cited papers, and keywords by using bibliometrics. This paper describes a bibliometric analysis regarding soil arsenic content by using the database from Web of Science to compare relevant research from work done domestically and abroad from 2005 to 2016. The results show that the relevant publications in China and overseas both dramatically increased from 2009, which indicates that research activity is expanding. The USA produced $27.3 \%$ of all relevant articles followed by China with $26.9 \%$ and India with $9.5 \%$. Key issues mainly focused on agriculture and environmental science. Major journals studied include the following: Science of the Total Environment, Environmental and Experimental Botany, Environmental Pollution, Chemosphere, Journal of Hazardous Materials, Journal of Environmental Chemical Engineering, Journal of Geochemical Exploration, Ecotoxicology and Environmental Safety, Environmental Research, Talanta, and Applied Geochemistry. These are the most important journals in this field. In light of cooperation between countries, it is clear that China and the United States occupy the leading position.
\end{abstract}

Key words: bibliometric; soil; arsenic; contamination; research

Cite this article as: CUI Meng-qian, WU Chuan, JIANG Xing-xing, LIU Zi-yu, XUE Sheng-guo. Bibliometric analysis of research on soil arsenic during 2005-2016 [J]. Journal of Central South University, 2019, 26(2): 479-488. DOI: https://doi.org/10.1007/s11771-019-4020-z.

\section{Introduction}

Arsenic (As) is a toxic heavy metal element and is widely distributed in nature, both as a result of natural processes and due to human activities; it can be released into groundwater and soil $[1,2]$. Arsenic contamination is common in rice [3]. Arsenic in the soil mainly migrates through the soil-plant system and finally enters the human body through the food chain [4]. The pollution severity and toxicity of arsenic compounds in the environment not only depend on its concentration but also depend on the main form of arsenic present and its bioavailability [5]. Arsenic can be present in various inorganic and organic forms in the environment and mainly occurs as $\mathrm{As}(\mathrm{V})$ [6]. In addition, studies have shown that the concentration and depth of soil arsenic have an inverse relationship [7]. Arsenic is of great concern to the public and is currently considered one of the most dangerous inorganic contaminants [8].

According to the relevant literature, arsenic, a ubiquitous element with metalloid properties, is most often found in environmental samples (soil, sediment, water, aerosol, rain, aquatics, vegetation,

\footnotetext{
Foundation item: Project(41771512) supported by the National Natural Science Foundation of China; Project(2018RS3004) supported by Hunan Science \& Technology Innovation Program, China

Received date: 2018-10-10; Accepted date: 2018-12-05

Corresponding author: WU Chuan, PhD, Professor; Tel: +86-15273172436; E-mail: wuchuan@csu.edu.cn; ORCID: 0000-0002-52593130
} 
milk, etc.). Speciation and distribution of arsenic have been widely studied in different regions. Arsenic originates from both natural and anthropogenic sources [9], and it widely exists in water, sediment and soil. Remediation of arsenic contaminated soils may change the nature of the soil to make arsenic more bioavailable [10]. Remediation of As-contaminated soil remains a major challenge in the field of environmental science and engineering. Bioremediation and passivation repair are commonly used for remediation, and phytoremediation is the most common method. Some industrial by products, such as red mud and phosphorus, can also be used to remediate soils contaminated by heavy metals [11]. Red mud has been proven to be highly effective for reducing heavy metal mobility in contaminated soil [12]. The risk of arsenic pollution in soil is closely related to the microbes present as microorganisms play an important role in the detoxification of arsenic [13]. The above research has provided a good foundation for further research.

At present, literature metrology has been recognized as one of the most active branches in the field of international library and information science and has entered the mainstream of information science research [14]. Bibliometrics is a useful tool to for analysing articles within a given research field; it is a research methodology employed in library and information sciences, and it utilizes statistics and quantitative analysis methods to describe distribution patterns of articles related to a given topic, field, institute or country $[15,16]$. These methods have recently been employed to investigate research trends in specific fields. Source, title, author, keyword, abstracts and funding agencies may also be introduced into the research trend study [17].

Therefore, studying soil arsenic pollution and its remediation technology has great significance. Levels of research covering arsenic pollution at home and abroad have definitely increased. In recent years, the problem of soil pollution has become more serious. Many studies from the past ten years cover all aspects of arsenic in our soils. We use the method of literature metrology to classify and summarize the related research, providing a solid platform for a more comprehensive understanding of soil arsenic.

\section{Methodology}

The methodology used in this research was similar to other bibliometric studies [18]. In this paper, through the retrieval of topic words, data were analyzed from the Web of Science. The time range is from 2005-2016. Approximately 700 data points were obtained from Web of Science. For bibliometric analysis, journal articles represented the majority of document types that also included whole research ideas and results. Downloaded information included names of authors, contact address, title, year of publication, author keywords, keywords plus, abstract, funding agencies, Web of Science categories of the article, and names of journals publishing the articles $[19,20]$.

This paper is based on a quantitative analysis of scientific knowledge in our area of interest. With the help of the information visualization software CiteSpaceII, which was developed by Dr. CHEN [21], the paper shows the active field and research frontier of bibliometrics. Creating a map of scientific knowledge is a type of research method that aims to bring the knowledge and information to the highest level of the most advanced field, and visually display the image. The specific method used in this paper is to use a frequency analysis of keywords to determine the areas of the highest research activity, the trend of the subject changes, and the research trends. Using literature metrology, we can analyze and summarize current research from the view of the core organization, the core author, the highly cited literature, and the country [22]. These findings provide a reference for the study of the subject.

\section{Results and discussion}

Results showed that research on arsenic contamination in soil has received much attention. A total of 15437 related documents were collected.

\subsection{Study of trends in research activity for a subject by using volume of documents}

The quantitative analysis of each year's literature, including the number and total citation index, was used to represent the trend of research activity for related fields in recent years. Published papers and citation frequency reflect the extent of related research, which is an important indicator of 
the level of scientific research and research object evaluation of bibliometric. These indicators are displayed in Table 1.

Table 1 Characteristics by year of publication outputs from 2005 to 2016.

\begin{tabular}{cccc}
\hline PY & TP & TC & TC/TP \\
\hline 2005 & 880 & 27430 & 31.17 \\
2006 & 965 & 26790 & 27.76 \\
2007 & 944 & 25050 & 26.54 \\
2008 & 1063 & 25070 & 23.58 \\
2009 & 1135 & 24550 & 21.63 \\
2010 & 1202 & 22360 & 18.60 \\
2011 & 1278 & 19590 & 15.33 \\
2012 & 1352 & 15170 & 11.22 \\
2013 & 1609 & 13130 & 8.16 \\
2014 & 1609 & 10150 & 5.72 \\
2015 & 1776 & 4638 & 2.61 \\
2016 & 1535 & 777 & 0.51 \\
\hline
\end{tabular}

PY: Published year; TP: Total publications; TC: Times cited; TC/TP: Average times cited.

The result of quantitative analysis of the database of soil arsenic from 2005-2016 is shown in Table 1, which shows that the number of literature occurrences in recent years is gradually increasing. This could reflect that the interest in soil heavy metal arsenic became a topic of intense interest, but the number of citations was lower. Notably, although the number of articles published in earlier years is relatively small, they fully describe the arsenic problem and are therefore referred to more frequently [23]. Therefore, in future research, we should undertake a deep analysis and discussion on the active issues to promote the development of research on heavy metal contamination in soil.

\subsection{Study of research trends according to volume of papers issued by country}

To explore the number of articles published by national ranking, we listed the analysis of the top nine countries. These data are shown in Table 2, and the leading countries could be determined from the article counts. The trend of paper counts is consistent with citations in the United States and China, which reflects that these two countries have high activity for research on soil arsenic. Other countries, such as India, also have paper counts
Table 2 Most productive countries for published research in field of soil arsenic during 2005-2016

\begin{tabular}{cccc}
\hline Country & TP & TC & TC/TP \\
\hline USA & 3109 & 54110 & 17.40 \\
China & 3063 & 45610 & 14.89 \\
India & 1092 & 15500 & 14.19 \\
Spain & 982 & 15952 & 16.24 \\
Germany & 638 & 11050 & 17.32 \\
Australia & 627 & 9278 & 14.92 \\
England & 627 & 10990 & 17.53 \\
Italy & 622 & 16470 & 26.27 \\
Canada & 616 & 10520 & 17.08 \\
\hline TP: Total publications; TC: Times cited; TC/TP: Average times \\
cited.
\end{tabular}

near the top of the list. However, the number of citations for soil arsenic is relatively low. This indicator needs to be further improved in terms of quantity and number of citations.

\subsection{Research on relevant topics by using core journals}

Shown in Table 3, these journals are widely recognized to be of high quality and academic value among published journals, Total Environmental Science is ranked first. The quantitative analysis of the issues of the journal includes three indicators: the number of published papers, citation frequency [24] and impact factor [25]. The number of published papers and citations reflects the degree of recognition in a given research field and the impact

Table 3 Leading journals showing research in field of soil arsenic during 2005-2016

\begin{tabular}{|c|c|c|c|c|}
\hline Journal & $\mathrm{TP}$ & $\mathrm{TC}$ & TC/TP & IF \\
\hline $\begin{array}{l}\text { Science of the Total } \\
\text { Environment }\end{array}$ & 713 & 14830 & 20.80 & 3.98 \\
\hline Journal of Hazardous Materials & 560 & 14720 & 26.29 & 4.84 \\
\hline Chemosphere & 510 & 10890 & 21.35 & 3.70 \\
\hline Environmental Pollution & 495 & 19357 & 39.11 & 4.84 \\
\hline $\begin{array}{c}\text { Environmental Monitoring and } \\
\text { Assessment }\end{array}$ & 444 & 3990 & 8.99 & 1.63 \\
\hline $\begin{array}{l}\text { Environmental Science and } \\
\text { Pollution Research }\end{array}$ & 426 & 2296 & 5.39 & 2.76 \\
\hline Water Air and Soil Pollution & 378 & 5252 & 13.89 & 1.55 \\
\hline Environmental Earth Sciences & 338 & 1808 & 5.35 & 1.77 \\
\hline Marine Pollution Bulletin & 270 & 4312 & 15.97 & 3.10 \\
\hline $\begin{array}{l}\text { Environmental Geochemistry } \\
\text { and Health }\end{array}$ & 276 & 4426 & 16.04 & 2.08 \\
\hline
\end{tabular}


factor of a journal indicates the scientific research level. Based on data from the Web of Science database, we analyzed the top ten journals by examining the number of citations and the impact factors of journals. The top four journals, whether we look at publication quantity, impact factor, or citation frequency are in the top tier, demonstrating that these journals are the most authoritative in the field of research covering heavy metals in soil. These journals are expected to influence the direction of future research. Article topics of the top ten journals are illustrated in Figure 1. There are 4192 related articles published in the top ten journals, resulting in an annual average of 349.3. We found the overall trend in number of articles published has increased from 2005 to 2016, while it dropped occasionally in some years. The reason for this phenomenon is probably the bottleneck period of the study [26].

According to the CiteSpace software, all documents mentioning soil arsenic were analyzed and plotted. We can see that the graph is roughly divided into four parts in Figure 2.

3.3.1. Arsenic contamination and behaviour in environment

The properties of arsenic have a significant impact on the environment. This has attracted global attention, with reporting from Australia,

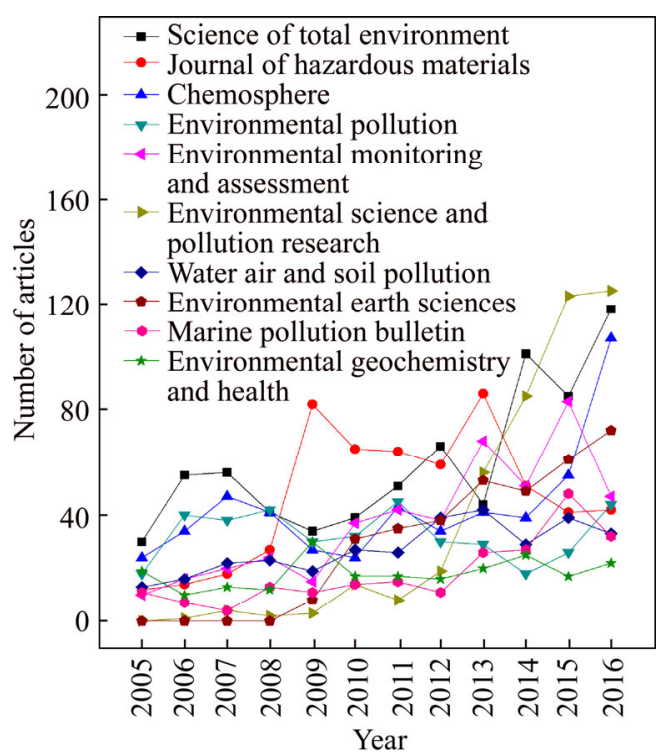

Figure 1 Publications of top ten productive Web of Science categories during 2005-2016

Nepal and other countries [27, 28]. Arsenic contaminates surrounding soils; plants then accumulate heavy metals from the soil. To some extent, these metals (including arsenic) change the food composition. Common foods such as rice, which contains large amounts of arsenic, present a toxicological issue [29]. The surrounding waters are also affected [30], mainly by entry into underground water [31]. Because groundwater is

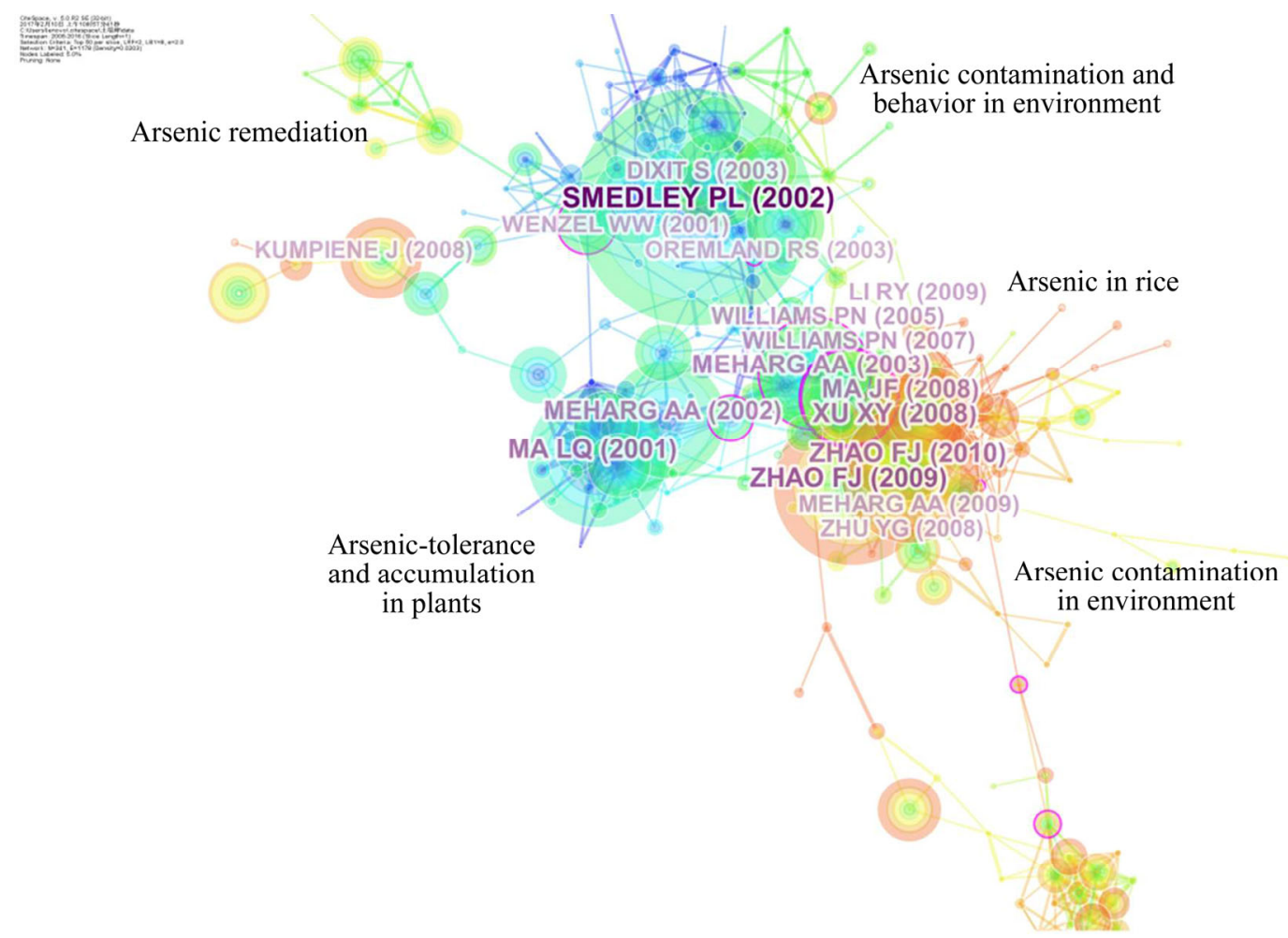

Figure 2 Co-citation analysis of documents based on CiteSpace data 
used for drinking water and irrigation to produce crops, it can harm human health. The concentration of arsenic in groundwater decreases gradually with the increase in depth. During periods of flooding, As is quickly released from soil into the water because of dissolution of $\mathrm{Fe}$ oxide and reduction of As from $\mathrm{As}(\mathrm{V})$ to $\mathrm{As}(\mathrm{III})$ [32]. Surface sediments may be impacted by geochemical and biological transformations of arsenic. The presence and types of arsenic in surface sediments are closely linked to early diagenetic processes [33].

3.3.2 Arsenic tolerance and accumulation in plants

A specific fern, resistant to arsenic, has contributed to the remediation of arsenic contaminated soils and is capable of absorbing large amounts of toxic heavy metals and isolating them from the ground [34]. Plants with these characteristics are called hyperaccumulators. This arsenic resistant fern clearly has potential value [35]. The speciation of arsenic is complex, and the variability of some plant responses to arsenic species helps us to understand the toxicity of arsenic and the way in which plants have evolved arsenic resistance [36]. The analysis of various hypertolerant and hyperaccumulator plants and comparison of their responses with non-tolerant and nonaccumulators have provided valuable information about the mechanisms of As tolerance and detoxification [37]. In Brazil, we have identified a new arsenic-tolerant plant species, Borreria verticillata. Specimens of Borreria verticillata from two sites were cultivated at different As and P concentrations [38]. Research shows that, at the lowest $\mathrm{P}$ and highest As concentrations, these plants demonstrated higher biomass. As an As-tolerant plant, Borreria verticillata could be successfully used for the remediation of contaminated soils [39]. Rice is a common plant in which accumulation of arsenic occurs. There were significant differences in arsenic uptake and accumulation among different rice varieties. There were also significant differences in the rates of oxygen permeation between different rice varieties. Therefore, we expect to be able to screen rice varieties for low arsenic accumulation by analyzing the oxygen permeability of rice [40].

3.3.3 Mitigation of arsenic contamination in environment

To reduce health risks, it is necessary to alleviate the toxicity and availability of As moving from the soil to edible portions of food. Oxidation, ion exchange, and phytoremediation technologies are available [41]. The immobilization of pollutants in soil can reduce the mobility and bioavailability of toxic elements. Immobilization promises to be important in agriculture, with crops being the focus [42]. Soil arsenic (As) contamination of food chains can be mitigated through fungal bioremediation for improved public health. These fungal strains can be used for As remediation in As-contaminated agricultural soils [43]. It has been reported that recombinant bacteria have been used for the bioremediation of arsenic [44]. The WHO and the United States Environmental Protection Agency attach great importance to the degree of pollution of drinking water, as the threshold level for arsenic in drinking water was lowered from $50 \mu \mathrm{g} / \mathrm{L}$ to $10 \mu \mathrm{g} / \mathrm{L}$ in 2001 [45]. Globally, Bangladesh is one of the countries with the highest arsenic pollution. The policy states that access to safe water for drinking and cooking shall be ensured through implementation of alternative water supply options in all arsenic impacted areas [46]. To date, bioremediation methods have not made much progress. It has been reported that recombinant bacteria have been used for the bioremediation of arsenic [44].

\subsubsection{Arsenic in rice}

The intake of arsenic by rice is appreciable, and the absorption of arsenic in rice is very significant. Therefore, countering the absorption mechanism of arsenic in rice is an important part of food safety [47]. Arsenic-contaminated rice may aggravate human health risks because this food is consumed in large quantities, especially in Asian countries [48]. Growing the hyperaccumulator (Pteris vittata) in arsenic-contaminated potted paddy soil resulted in a significant decrease in arsenic concentration after a period of nine months. The results demonstrate an effective decrease in bioavailable As from contaminated paddy soils, thereby reducing As uptake by rice $[49,50]$. The content of arsenic in different parts of rice and paddy soil is not the same [51]. Si is essential for maintaining good growth and a high yield of rice; silicate transport is responsible for arsenic transportation. Therefore, the influence of silicate as the main factor for arsenic speciation in soil and 
arsenic accumulation in rice plants was studied [52]. There were significant differences in root, straw and grain biomass among different rice genotype, and the application of $\mathrm{Si}$ significantly increased the biomass on root and grain. The effect of $\mathrm{Si}$ on reducing As accumulation in rice leaves was determined via SXRF [53]. Of course, oxygen conditions in the rice rhizosphere can also affect the expression of silicate transport. The accumulation and morphology of arsenic needs further study [54, 55].

\subsection{Study on research trends by using keywords}

As is shown in the diagram (Figure 3), the study of soil arsenic has been examined by keyword frequency. We have imported data from the Web of Science database to CiteSpace by using a collection of keywords to determine the research focus on soil arsenic [56]. Although the keywords take a small proportion in each article, typically only $3-5$ words, these keywords indicate the primary focus of each article [57]. Analysis of keywords in each article, especially those present with high frequency, has a major significance $[58,59]$. A small circle of nodes in the graph represents a keyword; the size of the keyword node represents the frequency [60]. It can be seen that soil, arsenic, heavy metal, accumulation, remediation and other nodes are relatively large. The figure indicates that these are the focus of research. According to the distribution of keywords, we can see that they cluster roughly around the same theme, which is divided into several areas of research [61]. It is generally divided into five main subthemes: arsenic pollution of the environment, remediation of arseniccontaminated soil, arsenic adsorption and fixation, effects of arsenic-contaminated soil on groundwater, and the toxicity of arsenic.

\subsection{Cooperation between different countries}

In modern science, communication and cooperation is becoming more and more important, especially when international cooperation has been the focus [62]. From the chart shown in Figure 4, we can see collaborative relationships between different countries; each circle is a node representing one country with publications, and the circle size is proportional to the number of papers published from this country [63]. Each node sends out branches connecting to other nodes, where each branch connects two countries with research cooperation [64]. With respect to international cooperation, we can highlight a number of countries with high levels of research, such as China, the United States, Australia, South Korea, India, Italy, Canada and Japan. These countries are leaders with respect to the level of scientific research globally, and there is close cooperation. Cooperative academic relationships have greatly promoted the advance of scientific research [65]. This paper

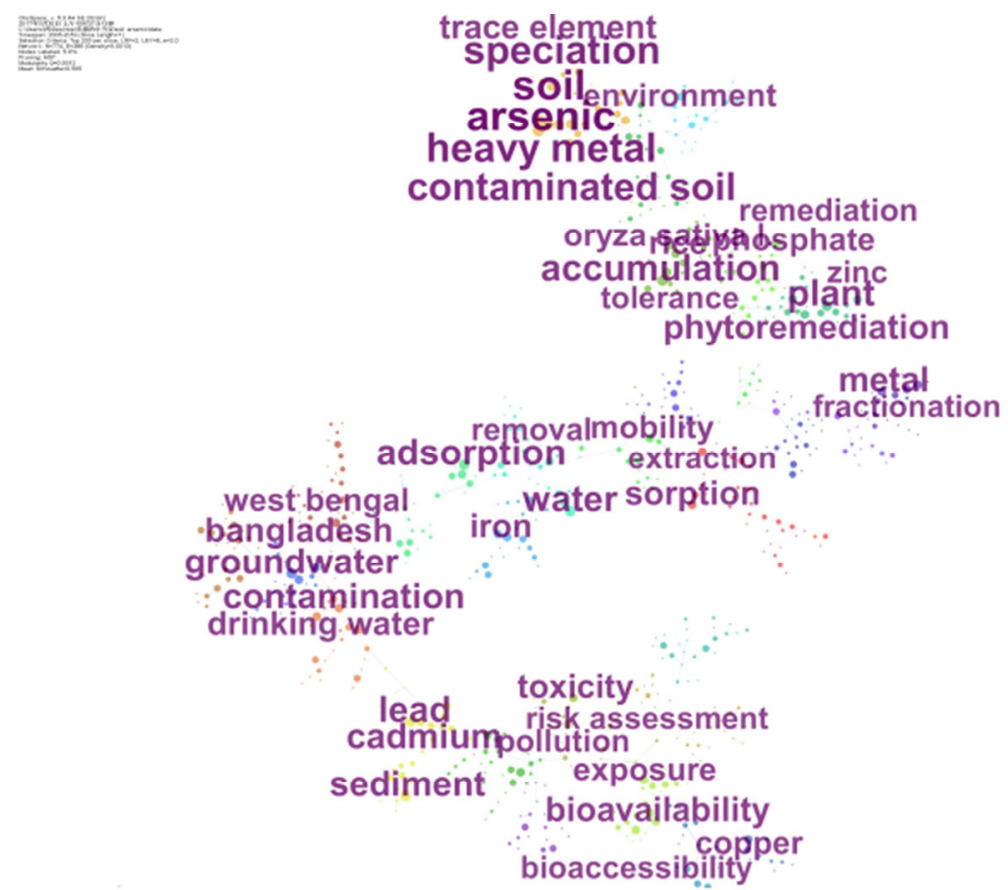

Figure 3 Cluster analysis of keywords based on CiteSpace 


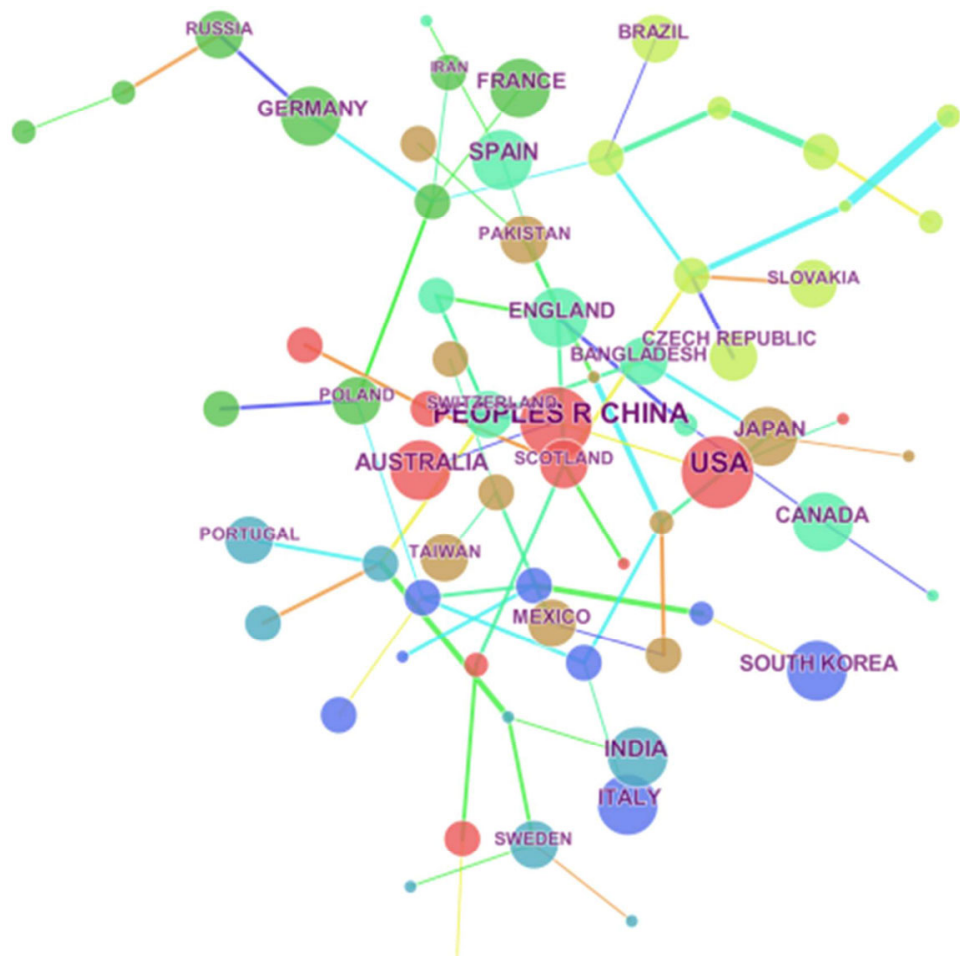

Figure 4 Cooperation of different countries

hopes to provide a direction for future researchers exploring the topic of soil arsenic so that they can better understand current and future research results and directions.

\section{Conclusions}

In this paper, soil arsenic was comprehensively analyzed from the perspective of subjects, keywords, journal and country by using the Web of Science. In recent years, more and more research regarding soil arsenic has been published in the literature, and this research has become an important topic and has attracted increasing attention worldwide. The United States, China, India, Spain, and other countries are among the leading publishers in this field. Most studies have focused on the toxicity, behaviour, remediation and accumulation of arsenic in arsenic-contaminated soils. Science of the Total Environment took the leading position sources used in total publications. Based on global research results, the following topics should be addressed in the field of soil arsenic research: 1) the remediation mechanism of arsenic-contaminated soil; 2) properties and regulation of arsenic-contaminated soil; 3) environmental risk assessment of remediation materials.

\section{References}

[1] HUANG Guan-huang, SUN Ji-chao, ZHANG Ying, JING Ji-hong, LIU Jing-tao. Distribution of arsenic in sewage irrigation area of Pearl River Delta, China [J]. Journal of Earth Science, 2011, 22(3): 396-410. DOI: 10.1007/s12583-011- 0192-7.

[2] WU Chuan, CUI Meng-qian, XUE Sheng-guo, LI Wai-chin, HUANG Liu, JIANG Xing-xing, QIAN Zi-yan. Remediation of arsenic-contaminated paddy soil by iron-modified biochar [J]. Environmental Science and Pollution Research, 2018, 25(21): 20792-20801. DOI: 10.1007/s11356-018-2268-8.

[3] KWON J C, NEJAD Z D, JUNG M C. Arsenic and heavy metals in paddy soil and polished rice contaminated by mining activities in Korea [J]. Catena, 2017, 148: 92-100. DOI: 10.1016/j.catena.2016.01.005.

[4] KRAMAR U, NORRA S, BEMER Z, KICZKA M, CHANDRASEKHARAM D. On the distribution and speciation of arsenic in the soil-plant-system of a rice field in West-Bengal, India: A $\mu$-synchrotron techniques based case study [J]. Applied Geochemistry, 2015, 77: 4-14. DOI: 10.1016/j.apgeochem.2015.11.006

[5] ZHU Feng, LIAO Jia-xin, XUE Sheng-guo, HARTLEY W, ZOU Qi, WU Hao. Evaluation of aggregate microstructures following natural regeneration in bauxite residue as characterized by synchrotron-based X-ray micro-computed tomography [J]. Science of the Total Environment, 2016, 573(24): 155-163. DOI: 10.1016/j.scitotenv.2016.08.108.

[6] ZHANG Xin, REN Bai-hui, WU Song-lin, SUN Yu-qing, LIN Ge, CHEN Bao-dong. Arbuscular mycorrhizal symbiosis influences arsenic accumulation and speciation in Medicago truncatula L. in arsenic-contaminated soil [J]. 
Chemosphere, 2015, 119(1): 224-230. DOI: 10.1016/ j.chemosphere.2014.06.042.

[7] KARAK T, ABOLLINO O, BHATTACHARYYA P, DAS $\mathrm{K} \mathrm{K}, \mathrm{PAUL} \mathrm{R} \mathrm{K}$. Fractionation and speciation of arsenic in three tea gardens soil profiles and distribution of As in different parts of tea plant (Camellia sinensis L.) [J]. Chemosphere, 2011, 85(6): 948-960. DOI: 10.1016/ j.chemosphere.2011.06.061.

[8] MARTIN M, BONIFACIO E, HOSSAIN K M J, HUQ S M I, BARBERIS E. Arsenic fixation and mobilization in the soils of the Ganges and Meghna floodplains. Impact of pedoenvironmental properties [J]. Geoderma, 2014, 228-229(7): 132-141. DOI: 10.1016/j.geoderma.2013.09. 020 .

[9] RASOOL A, FAROOQI A, XIAO T F, MASOOD S, KAMRAN M A, BIBI S. Elevated levels of arsenic and trace metals in drinking water of Tehsil Mailsi, Punjab, Pakistan [J]. Journal of Geochemical Exploration, 2016, 169: 89-99. DOI: 10.1016/j.gexplo.2016.07.013.

[10] WENZEL W W, KIRCHBAUMER N, PROHASKA T, STINGEDER G, LOMBI E, ADRIANO D C. Arsenic fractionation in soils using an improved sequential extraction procedure [J]. Analytica Chimica Acta, 2001, 436(2): 309-323. DOI: 10.1016/S0003-2670(01)00924-2.

[11] WANG Jun, CHENG Qing-yu, XUE Sheng-guo, RAJENDRAN M, WU Chuan, LIAO Jia-xin. Pollution characteristics of surface runoff under different restoration types in manganese tailing wasteland [J]. Environmental Science and Pollution Research, 2018, 25(10): 9998-10005. DOI: $10.1007 / \mathrm{s} 11356-018-1338-2$.

[12] XUE Sheng-guo, WU Yu-jun, LI Yi-wei, KONG Xiang-feng, ZHU Feng, WILLIAM Hartley, LI Xiao-fei, YE Yu-zhen. Industrial wastes applications for alkalinity regulation in bauxite residue: A comprehensive review [J]. Journal of Central South University, 2019, 26(2): 268-288.

[13] WU Chuan, HUANG Liu, XUE Sheng-guo, SHI Li-zheng. Review on the application of bauxite residue on As contamination remediation [J]. Environmental Chemistry, 2016, 35(1): 141-149. (in Chinese)

[14] PANDEY N, BHATT R. Role of soil associated Exiguobacterium, in reducing arsenic toxicity and promoting plant growth in Vigna radiate [J]. European Journal of Soil Biology, 2016, 75: 142-150. DOI: 10.1016/j.ejsobi.2016.05. 007.

[15] ZHANG Hong-liang, TIAN Ling, ZHANG Li-li. Preliminary study on discipline hotspots by bibliometrics [J]. Journal of Medical Informatics, 2008(11): 11-16. (in Chinese)

[16] XUE Sheng-guo, WANG Jun, WU Chuan, SHI Li-zheng, HARTLEY William, WU Hao, ZHU Fu, CUI Meng-qian. Physiological response of Polygonum perfoliatum $\mathrm{L}$. following exposure to elevated manganese concentrations [J]. Environmental Science and Pollution Research, 2018, 25(1): 132-140. DOI: 10.1007/s11356-016-8312-7.

[17] WANG Qiang, YANG Zhao-guang, YANG Yuan, LONG Chen-lu, LI Hai-pu A bibliometric analysis of research on the risk of engineering nanomaterials during 1999-2012 [J]. Science of the Total Environment, 2014, 473-474(3): 483-489. DOI: 10.1016/j.scitotenv.2013.12.066.

[18] HO Y S. Bibliometric analysis of biosorption technology in water treatment research from 1991 to 2004 [J]. International
Journal of Environment \& Pollution, 2008, 34(1-4): 1-13. DOI: 10.1504/IJEP.2008.020778.

[19] XEU Sheng-guo, YE Yu-zhen, ZHU Feng, WANG Qiong-li, JIANG Jun, HARTLEY W. Changes in distribution and microstructure of bauxite residue aggregates following amendments addition [J]. Journal of Environmental Sciences, 2019, 78: 276-286. DOI: 10.1016/j.jes.2018.10.010.

[20] CHIU W T, HUANG J S, HO Y S. Bibliometric analysis of Severe Acute Respiratory Syndrome-related research in the beginning stage [J]. Scientometrics, 2004, 61(1): 69-77. DOI: 10.1023/b:scie.0000037363.49623.28.

[21] CHEN Chao-mei. CiteSpace II: Detecting and visualizing emerging trends and transient patterns in scientific literature [J]. Journal of the China Society for Scientific \& Technical Information, 2014, 57(3): 359-377. DOI: 10.1002/asi.20317.

[22] SAHA S, SAINT S, CHRISTAKIS D A. Impact factor: A valid measure of journal quality? [J]. Journal of the Medicine Library Association, 2003, 91(1): 42-46. DOI: doi:10.1002/ asi.10171.

[23] LI Zhi-tao. The growth trend and dynamic distribution region of library literature in recent 20 years [J]. Journal of Modern Information, 2010(8): 32-35. (in Chinese)

[24] WANG S, MULLIGAN C N. Occurrence of arsenic contamination in Canada: Sources, behavior and distribution [J]. Science of the Total Environment, 2006, 366(2): 701-721. DOI: 10.1016/j.scitotenv.2005.09.005.

[25] OLIVEIRA L M D, MASSAHUD R T L R, SOUZA E S D, FEMANDES A R. Arsenic: behavior in the environment, plant uptake mechanisms and human health risks [J]. Revista De Ciências Agrárias, 2014, 43(s9-11): 1731-1736. DOI: 10.4322/rca.ar1558.

[26] SACCO L D, BALDASSARRE A, MASOTTI A. Diet's role in the toxicity of inorganic arsenic (iAs): A journey from soil to children's mouth [J]. Journal of Geochemical Exploration, 2013, 131: 45-51. DOI: 10.1016/j.gexplo.2012.11.014.

[27] KIM M J, NRIAGU J, HAACK S. Arsenic behavior in newly drilled wells [J]. Chemosphere, 2003, 52(3): 623-633. DOI: 10.1016/S0045-6535(03)00244-3.

[28] SMEDLEY P L, KINNIBURGH D G. A review of the source, behaviour and distribution of arsenic in natural waters [J]. Applied Geochemistry, 2002, 17(5): 517-568. DOI: 10.1016/S0883-2927(02)00018-5.

[29] TAKAHASHI Y, MINAMIKAWA R, HATTORI K H, KURISHIMA K, KIHOU N. Arsenic behavior in paddy fields during the cycle of flooded and non-flooded periods [J]. Environmental Science \& Technology, 2004, 38(4): 1038-1044. DOI: 10.1021/es034383n.

[30] GOMY J, BILLON G, LESVEN L. Arsenic behavior in river sediments under redox gradient: A review [J]. Science of the Total Environment, 2015, 505: 423-434. DOI: 10.1016/ j.scitotenv.2014.10.011.

[31] XUE Sheng-guo, LI Meng, JIANG Jun, MILLAR G J, LI Chu-xuan, KONG Xiang-feng. Phosphogypsum stabilization of bauxite residue: Conversion of its alkaline characteristics [J]. Journal of Environmental Sciences, 2019, 77: 1-10. DOI: 10.1016/ j.jes.2018.05016.

[32] MEHARG A A, HARTLEY-WHITAKER J. Arsenic uptake and metabolism in arsenic resistant and nonresistant plant species [J]. New Phytologist, 2010, 154(1): 29-43. DOI: 10.1046/j.1469-8137.2002.00363.x. 
[33] SRIVASTAVA S, SUPRASANNA P, D'SOUZA S F. Mechanisms of arsenic tolerance and detoxification in plants and their application in transgenic technology: A critical appraisal [J]. International Journal of Phytoremediation, 2012, 14(5): 506-517. DOI: 10.1080/15226514.2011. 604690.

[34] WANG J, ZHAO F J, MEHARG A A, RAAB A, FELDMANN J, MCGRATH S P. Mechanisms of arsenic hyperaccumulation in Pteris vittata. Uptake kinetics, interactions with phosphate, and arsenic speciation [J]. Plant Physiology, 2002, 130(3): 1552. DOI: 10.1104/pp.008185.

[35] KLEIN S, HAGE J J. Measurement, calculation, and normal range of the ankle-arm index: A bibliometric analysis and recommendation for standardization [J]. Annals of Vascular Surgery, 2006, 20(2): 282-292. DOI: 10.1007/s10016-0069019-X.

[36] CHUN Y, SHENG G, CHIOU C T, XING B. Compositions and sorptive properties of crop residue-derived chars [J]. Environmental Science \& Technology, 2004, 38(17): 4649. DOI: $10.1021 / \mathrm{es} 035034 \mathrm{w}$.

[37] SINGH R, SINGH S, PARIHAR P, SINGH V P, PRASAD S M. Arsenic contamination, consequences and remediation techniques: A review [J]. Ecotoxicology \& Environmental Safety, 2015, 112: 247-270. DOI: 10.1016/j.ecoenv.2014. 10.009 .

[38] KUMPIENE J, LAGERKVIST A, MAURICE C. Stabilization of $\mathrm{As}, \mathrm{Cr}, \mathrm{Cu}, \mathrm{Pb}$ and $\mathrm{Zn}$ in soil using amendments - A review [J]. Waste Management, 2008, 28(1): 215-225. DOI: 10.1016/j.wasman.2006.12.012.

[39] SHAKOOR M B, NIAZI N K, BIBI I, MURTAZA G, KUNHIKRISHNAN A, SESHADRI B. Remediation of arsenic-contaminated water using agricultural wastes as biosorbents [J]. Critical Reviews in Environmental Science \& Technology, 2016, 46(5): 467-499. DOI: 10.1080/ 10643389.2015.1109910.

[40] AHMED M F, AHMED T. 1.8-status of remediation of arsenic contamination of groundwater in Bangladesh [J]. Comprehensive Water Quality \& Purification, 2014: 104-121. DOI: 10.1016/B978-0-12-382182-9.00002-5.

[41] FATEHI F, WOOTTON R. Telemedicine, telehealth or e-health? A bibliometric analysis of the trends in the use of these terms [J]. Journal of Telemedicine \& Telecare, 2012, 18(8): 460-464. DOI: 10.1258/jtt.2012.GTH108.

[42] MA J F, YAMAJI N, MITANI N, XU X Y, SU Y H, MCGRATH S P, ZHAO F J. Transporters of arsenite in rice and their role in arsenic accumulation in rice grain [J]. Proceedings of the National Academy of Sciences of the United States of America, 2008, 105(29): 9931-9935. DOI: 10.1073/pnas.0802361105.

[43] ZOU Li-na, DAI Yu-xia, QIU Wei-di, ZHANG Shu, ZHAO Jia-wei, TANG Xian-jin, SHI Ji-yan, XU Jian-ming. Effect of sulfur on the bioavailability of arsenic in soil and its accumulation in rice plant (Oryza sativa L.) [J]. Journal of Agro-Environment Science, 2018, 37(7): 1435-1447. DOI: 10.11654/jaes.2018-0837.

[44] LIN S C, CHANG T K, HUANG W D,LUR H S, SHYU G S. Accumulation of arsenic in rice plant: A study of an arsenic-contaminated site in Taiwan [J]. Paddy \& Water Environment, 2015, 13(1): 11-18. DOI: 10.1007/s10333013-0401-3.
[45] YE W L, KHAN M A, MCGRATH S P, ZHAO F J. Phytoremediation of arsenic contaminated paddy soils with Pteris vittata, markedly reduces arsenic uptake by rice [J]. Environmental Pollution, 2011, 159(12): 3739-3743. DOI: 10.1016/j.envpol.2011.07.024.

[46] MANDAL A, PURAKAYASTHA T J, PATRA A K, SANYAL S K. Phytoremediation of arsenic contaminated soil by Pteris Vittata L. II. Effect on arsenic uptake and rice yield [J]. International Journal of Phytoremediation, 2012, 14(6): 621-628. DOI: 10.1080/15226514.2011.619228.

[47] GUO W, HOU Y L, WANG S G, ZHU Y G. Effect of silicate on the growth and arsenate uptake by rice (Oryza sativa L.) seedlings in solution culture [J]. Plant \& Soil, 2005, 272(1, 2): 173-181. DOI: 10.1007/s11104-004-4732-0.

[48] WU Chuan, ZOU Qi, XUE Sheng-guo, PAN Wei-song, YUE Xu, HARTLEY William, HUANG Liu, MO Jing-yu. Effect of silicate on arsenic fractionation in soils and its accumulation in rice plants [J]. Chemosphere, 2016, 165: 478-486. DOI: 10.1016/j.chemosphere.2016.09.061.

[49] WU Chuan, HUANG Liu, XUE Sheng-guo, PAN Wei-song, ZOU Qi, HARTLEY William, WONG Ming-huang. Oxic and anoxic conditions affect arsenic (As) accumulation and arsenite transporter expression in rice [J]. Chemosphere, 2017, 168: 969-975. DOI: 10.1016/j.chemosphere.2016. 10.114 .

[50] CHEN Guo, XIAO Lu. Selecting publication keywords for domain analysis in bibliometrics: A comparison of three methods [J]. Journal of Informetrics, 2016, 10(1): 212-223. DOI: 10.1016/j.joi.2016.01.006.

[51] SURAUD M G, QUONIAM L, ROSTAING H, DOU H. On the significance of data bases keywords for alarge scale bibliometric investigation in fundamental physics [J]. Scientometrics, 1995, 33(1): 41-63. DOI: 10.1007/ BF02020774.

[52] XIE Shao-dong, ZHANG Jing, HO Y S. Assessment of world aerosol research trends by bibliometric analysis [J]. Scientometrics, 2008, 77(1): 113-130. DOI: 10.1007/ s11192-007-1928-0.

[53] LI Ling-li, DING Guo-hua, FENG Nan, WANG Ming-huang, HO Yuh-shan. Global stem cell research trend: Bibliometric analysis as a tool for mapping of trends from 1991 to 2006 [J]. Scientometrics, 2009, 80(1): 39-58. DOI: $10.1007 /$ s11192-008-1939-5.

[54] LEEUWEN T N V. Strength and weakness of national science systems: A bibliometric analysis through cooperation patterns [J]. Scientometrics, 2009, 79(2): 389-408. DOI: 10.1007/s11192-009-0426-y.

[55] AL-MAAWALI A, AL B A, AL-ADAWI S. Biomedical publications profile and trends in gulf cooperation council countries [J]. Sultan Qaboos University Medical Journal, 2012, 12(1): 41. DOI: 10.1080/02533839.2006.9671161.

[56] SINGH M, SRIVASTAVA P K, VERMA P C, KHARWAR $\mathrm{R} N$, SINGH N. Soil fungi for mycoremediation of arsenic pollution in agriculture soils [J]. Journal of Applied Microbiology, 2015, 119(5): 1278-1290. DOI: 10.1111/ jam.12948.

[57] LEBLANC M S, LIMA A, MONTELLO P, KIM T, MEAGHER R B, MERKLE S. Enhanced arsenic tolerance of transgenic eastern cottonwood plants expressing gammaglutamylcysteine synthetase [J]. International Journal of 
Phytoremediation, 2011, 13(7): 657-673. DOI: 10.1080/ 15226514.2010.499917.

[58] WU Chuan, YE Zhi-hong, SHU Wen-sheng, ZHU Yong-guan, WONG Ming-hung. Arsenic accumulation and speciation in rice are affected by root aeration and variation of genotypes [J]. Journal of Experimental Botany, 2011, 62(8): 2889-2898. DOI: 10.1093/jxb/erq462.

[59] GUHA MAZUMDER D N. Chronic arsenic toxicity \& human health [J]. Indian Journal of Medical Research, 2008, 128(4): 436-447. DOI: http://imsear.hellis.org/handle/ 123456789/ 18399 .

[60] BOLAN N, MAHIMAIRAJA S, KUNHIKRISHNAN A, NAIDU R. Sorption-bioavailability nexus of arsenic and cadmium in variable-charge soils [J]. Journal of Hazardous Materials, 2013, 261(20): 725-732. DOI: 10.1016/j.jhazmat. 2012.09.074.

[61] MANDAL P. An insight of environmental contamination of arsenic on animal health [J]. Emerging Contaminants, 2017, 3(1): 17-22. DOI: 10.1016/j.emcon.2017.01.004.

[62] CHEN Chao-mei. CiteSpace II: Detecting and visualizing emerging trends and transient patterns in scientific literature [J]. Journal of the China Society for Scientific \& Technical Information, 2014, 57(3): 359-377. DOI: 10.1002/asi.20317.

[63] ASMEL N K, YUSOFF A R M, KRISHNA L S, MAJID Z A, SALMIATI S. High concentration arsenic removal from aqueous solution using nano-iron ion enrich material (NIIEM) super adsorbent $[\mathrm{J}]$. Chemical Engineering Journal, 2017, 317: 343-355. DOI: 10.1016/j.cej.2017.02.039.

[64] JACKSON B P, MILLER W P. Effectiveness of phosphate and hydroxide for desorption of arsenic and selenium species from iron oxides [J]. Soil Science Society of America Journal, 2000, 64(5): 1616-1622. DOI: 10.2136/sssaj2000. 6451616x.

[65] ZOU Qi, AN Wen-hui, WU Chuan, LI Wai-chin, FU An-qing, XIAO Rui-yang, CHEN Hui-kang, XUE Sheng-guo. Red mud-modified biochar reduces soil arsenic availability and changes bacterial composition [J]. Environmental Chemistry Letters, 2018, 16: 615-622. DOI: 10.1007/s10311-017-0688-1.

(Edited by YANG Hua)

\section{中文导读}

\section{5-2016 年关于土壤砷研究的文献计量分析}

摘要: 文献计量学是信息科学领域的一个重要分支, 在现代研究的许多学科中都有广泛的应用。利用 文献计量学方法, 可以从核心机构、核心作者、高引论文、关键词等多个方面对当前热点的研究课题 进行分析和总结。本文利用 Web of Science 数据库对 2005-2016 年国内外有关土壤砷方向的相关研 究领域进行了文献计量分析。结果表明, 自 2009 年以来, 国内外相关出版物均大幅增加, 表明该研 究方向的趋势逐渐增加。美国在所有相关文章中占 $27.3 \%$, 中国占 $26.9 \%$, 印度占 $9.5 \%$ 。主要问题集 中在农业和环境科学方面。主要研究期刊包括: Science of the Total Environment, Environmental and Experimental Botany, Environmental Pollution, Chemosphere, Journal of Hazardous Materials, Journal of Ecotoxicology and Environmental Safety 等。这些是这一领域最重要最权威的期刊。从各国合作的角度 来看, 中美两国显然占据了主导地位。

关键词：文献计量学；土壤；砷；污染；研究 